\section{Kastamonu Eğitim Dergisi Kastamonu Education Journal}

Eylül 2019 Cilt:27 Sayı:5

kefdergi.kastamonu.edu.tr
Başvuru Tarihi/Received: 12.12.2018

Kabul Tarihi/Accepted: 07.02.2019

DOI: $10.24106 /$ kefdergi.3467

\title{
Analitik Kimya Laboratuar Uygulamasında Örnek-Olaya Dayalı Öğrenmenin Kullanıldığı Bir Materyal Geliştirilmesi ve Öğrenci Görüşleri
}

\section{Development a Material Used in Case-Based Learning for Analytical Chemistry Laboratory Application and Students' Views}

\section{Öz}

\author{
Tuğçe GÜNTER ${ }^{1}$, Sibel KILINÇ ALPAT ${ }^{2}$
}

Bu çalışmanın amacı, örnek olay ve örnek-olaya dayalı öğrenmeye ilişkin öğrenci görüşlerini araşttrmaktır. Örnek olay, Analitik Kimya Laboratuarı dersi suların sertliğinin belirlenmesi deneyinde etilen diamin tetra asetik asit bileşiği (EDTA) ile metal iyonlarının kompleks oluşum reaksiyonlarına dayalı kompleks oluşum titrasyonuyla ilgili olarak hazırlanmıştr. Bu betimleyici çalışmanın örneklemi, İzmir'de bir üniversitede Kimya Öğretmenliği bölümünde okuyan ikinci, dördüncü ve beşinci sınıf öğretmen adaylarından ( $N=23)$ (20-23 yaşlar arasında) oluşmuştur. 'Yapılandırılmış Görüşme Formu' veri toplama aracı olarak kullanılmıştır. Veriler, nitel analiz tekniklerinden içerik analiziyle analiz edilmiştir. Elde edilen verilere göre; öğrenciler örnek-olaya dayalı öğrenme yönteminin kapsamlı ve uygun olduğunu belirtmişlerdir. Ayrıca hazırlanan örnek olayın araştırma yapma isteklerini ve motivasyonlarını arttırarak öğrenmelerini eğlenceli hale getirdiğine dair olumlu görüşlerde de bulunmuşlardır.

Anahtar Kelimeler: analitik kimya laboratuarı, öğrenci görüşleri, örnek-olaya dayalı öğrenme, suyun sertliğinin belirlenmesi

\begin{abstract}
The objective of this study is to investigate students' views about the case study and case-based learning (CBL). The case study is prepared concerning the complex formation titration based on ethylene diamine tetra acetic acid compound (EDTA) and complex formation reaction of metal ions and the experiment of hardness determination in water in the Analytical Chemistry Laboratory course. The sample of this descriptive study consists of $2^{\text {nd }}, 4^{\text {th }}$ and $5^{\text {th }}$ grade student teachers ( $\mathrm{N}=23$ ) (ages between 20-23 years-old) studying in the department of Chemistry Teaching at a university in Izmir. 'Structured Interview Form' was used as data collection tool. The data were analyzed via content analysis, which is a qualitative analysis technique. According to the data obtained; the students stated that the CBL method was comprehensible and convenient. In addition, they had also positive views that the case study being prepared was an entertaining study building up the desire for investigation and motivation.
\end{abstract}

Keywords: analytical chemistry laboratory, case-based learning, hardness determination in water, students' views

1. Zonguldak Bulent Ecevit University, Ahmet Erdogan Vocational School of Health Services, Zonguldak, Turkey; https://orcid.org/0000-0001-7416-2967 2. Dokuz Eylul University, Buca Education Faculty, Izmir, Turkey; https://orcid.org/0000-0001-7149-3779

Atif / Citation: Günter, T. \& Alpat, S. K. (2019). Development a material used in case-based learning for analytical chemistry laboratory application and students' views. Kastamonu Education Journal, 27(5), 2261-2278. doi:10.24106/kefdergi.3467 


\section{Extended Abstract}

Introduction: Case-based learning (CBL) method, which is derived from the approach of problem-based learning (PBL) based on the constructivist approach, is an active learning method where learners use metacognitive thinking skills such as analysis and synthesis. The cases are small scenarios in which students read, explore, discuss interactively and debate dynamically. CBL is an active learning method that enables students to combine knowledge and concepts with real life conditions and bridges between theory and practice. In this context, it is important to use CBL in chemistry laboratory applications (Garnett, Garnett, \& Hackling,1995; Jarz, Kainz, \&Walpoth, 1997). It is thought that it would be efficient to use the CBL, which is supported by daily life problems, in the applications of the Analytical Chemistry Laboratory course. Undergraduate program of Chemistry Teaching involves students' ability of realizing complex formation titrations, interpreting titration types, making quantitative calculations and evaluating the calculation errors by statistical analysis data within the scope of the Analytical Chemistry Laboratory course. If students practically get this knowledge by solving daily life problems, they might acquire metacognitive thinking skills and increase their achievement, motivation and attitudes. In this context, views of students about the CBL, case study and the developed material are thought to be important. This study is important as it is among the limited number of studies using the CBL concerning "hardness determination in water via EDTA", which is an application of complex formation titrations, and it would pave the way for developing an efficient material on this issue (Bholah, 2017; Cheng, 1995; Kumar, 2017; Ram, 1999). For instance, Cam and Geban (2011) concluded that the CBL method that was applied concerning 'Water Hardness' was effective upon increasing the epistemological beliefs of students and their positive attitudes toward chemistry course.

Method: The sample of this descriptive study consists of $2^{\text {nd }}, 4^{\text {th }}$ and $5^{\text {th }}$ grade pre-service student teachers $(n=23)$ (ages between 20-23 years-old) studying Chemistry Teaching at a university in Izmir, Turkey. The students were primarily informed about the CBL method. After that, case study was given to each of the students and students were separated to the groups composed of two students. These groups were discussed on the case study, developed material's name, applicability and experimental procedure design by using brainstorming technique. Finally, all students were reported their views individually in written form. Therefore, 'structured interview form' was used as data collection tool in this research. The questions in the structured interview form that was used in the study were analyzed via content analysis. In the research, a case titled "Acarel-2016: Don't Let the Colors Fade" was prepared in relation with daily life by using the relevant literature and receiving the opinions of two analytical chemistry laboratory and pedagogical experts in the Analytical Chemistry Laboratory course. Consisting of two parts; the scenario is related with a laborant named Acar, who worked on surface active substances in laundry detergents preventing the laundry colors from fading. The scenario was prepared based on the investigations of the laborant concerning how the EDTA compound was effective upon colors. This scenario was prepared for the purpose of enabling the students to determine hardness in different waters like tap water, spring water and distillate water via the titration method by using the EDTA compound. The scenario also involves parts like 'Did You Know That?' concerning the usage areas of the EDTA compound and its effects upon human health.

Results and Discussion: As a result of content analysis, it was seen that the students have higher rates of positive views (86.84\%) than negative views (13.16\%) about the CBL method, the developed material and the case study. This finding has shown that the method could be applied in the analytical chemistry laboratory course concerning "hardness determination in water via EDTA".

Conclusion: The study shows that the tool could be effective for the undergraduate students in analytical chemistry laboratory course. Majority of students expressed positive views about the method and suggested that it was remembered easily, related with daily life and that the material and the case study were convenient, comprehensible and instructive.

Implications: It is suggested that the case study and the material developed in the study could be efficiently used in "hardness determination in water via EDTA" and supported by additional materials to be prepared according to the recommendations of students. It is considered that after the case study and the material to be developed in the next study are applied in the laboratory environment, the effect of CBL upon students' academic achievement, metacognitive skills and attitudes toward chemistry course could be examined. 


\section{Introduction}

It is very important to comprehend and interpret the place of chemistry in daily life because the science of chemistry contributes to many developments in the fields of health, medicine, forensic chemistry and environment. Laboratory applications have a great contribution to learning the usage areas of chemistry and associating the chemistry with daily life. Laboratory applications will enable learners to acquire the skills of observing, discussing, problem solving, critical and mathematical thinking (Australian Education Council, 1994; Figueiredo, Esteves, Neves, \&Vicente,2016; Harman, Cokelez, Dal,\&Alper, 2016; Hofstein, 2004; McDonnell, O'Connor, \&Seery, 2007). Being based on a constructivist approach; laboratory studies play an important role in increasing the learning achievements of learners and enabling them to develop positive attitudes toward chemistry course, compared to the conventional teacher-based approach (Figueiredo, Esteves, Neves, \&Vicente, 2016; Shiland, 1999).

Case-based learning (CBL) method, which is derived from the approach of problem-based learning (PBL) based on the constructivist approach, is an active learning method where learners use metacognitive thinking skills such as analysis and synthesis. Cases are small scenarios in which students read, explore, discuss interactively and debate dynamically. In this context, it is important to use CBL in chemistry laboratory applications (Garnett, Garnett, \& Hackling,1995; Jarz, Kainz, \&Walpoth, 1997; Merseth, 1991; Woolnough \& Allsop,1985; Yalcınkaya, Boz, \&Erdur-Baker,2012).

For instance, Bholah (2017) implemented PBL concerning water-related issues for the secondary school level of students. As a result of this study, it was concluded that PBL could foster students' information about water management. In the case study of Kumar (2017), it was implemented technology supported PBL in science, technology, engineering and mathematics for the topic of water quality. In this research, students made discussions concerning $\mathrm{pH}$, dissolved oxygen, temperature of the river ecosystem and water quality index. It was determined that this case study enabled a framework in designing technology supported PBL science, technology, engineering and mathematics.

Kerr and Yan (2016) conducted a study using PBL in analytical and instrumental analysis chemistry laboratory applications and concluded that students were more excited in the career of chemistry and had positive opinions about the application. In their study; Owens, Zimmerman, Gardner, and Lowe (2016) analyzed the compounds within whiskey in an analytical chemistry laboratory in accordance with green chemistry. As a result of the study, they determined that students found conducting analysis on a sample from real life more interesting.

Jansson, Söderström, Andersson, and Nording (2015) investigated whether the PBL was an effective instructional approach for students in order to be taught the topics of Environmental Chemistry in the undergraduate level. In this study, the scenario was based on the topics such as emissions, sources, transport, transformation, chemical structures and functions of organic and inorganic substances in the environment, the effects of hazardous compounds on environment and on human health and risk assessment of these compounds. They concluded that the students had positive opinions such as depth understanding of these topics by PBL and group work. In the study conducted by Belova and Eilks (2015), they concluded that the case study applied to primary school students in chemistry course concerning the "chemistry of natural cosmetics" enabled students to comprehend the critical media literacy and associate the knowledge of chemistry with advertising. Tarkın (2014) conducted a study by using the CBL method and concluded that the method enabled secondary school students to understand the subject of electrochemistry, increased their motivation and caused them to display positive attitudes toward chemistry course. Yalcınkaya, Boz, and Erdur-Baker (2012) determined that the CBL method applied in secondary education chemistry course was effective upon increasing the motivation of students toward the course in their research.

As a result of their study where they applied chemical activities related with daily life based on the $5 \mathrm{E}$ model in the subject of chemical changes in secondary education chemistry course; Kocak and Onen (2012) observed a positive increase in the achievements of students and their attitudes toward chemistry course. Cam and Geban (2011) concluded that the CBL method that was applied concerning 'Water Hardness' was effective upon increasing the epistemological beliefs of students and their positive attitudes toward chemistry course. Kılınc Alpat, Uyulgan, Ozbayrak, and Alpat (2011) determined that the CBL method that was applied for discovering the ionization constant of weak acid in the undergraduate level chemistry laboratory course helped students develop positive attitudes toward the course.

Williams, Woodward, Symons, and Davies (2010) developed and implemented PBL module for the topic of 'The Principles of Chemistry' in the course of Inorganic/Physicochemistry in the undergraduate level. In the study, virtual learning environments were also prepared for students in order to work in cooperation. It was concluded that the students gained transferable and collaborative working skills and developed their understanding the relevant topic.

| Kastamonu Eğitim Dergisi, 27(5), 2019 | 
As a result of his study using the CBL method concerning the topic of solubility balance in chemistry course; Cam (2009) determined that it was an efficient method for correcting the conceptual comprehension of students and increasing their comprehension. In the study of Choi and Lee (2009), it was determined that the CBL increased the problem solving skills of students; however, students had a difficulty in combining multi-directional opinions in group work in practice.

Marks, Bertram, and Eilks (2008) examined the effect of PBL about the topic of 'Carbohydrates and Lipids' on students' learning. In the research, the topic of developed scenario was based on the discussion about the daily low-fat and low-carbohydrate foods in the media. The students also conducted an experiment about this topic. As a result of this study, it was determined that PBL developed the socio-critical skills of the students and increased their learning.

McDonnell, O'Connor, and Seery (2007) used both the laboratory teaching method as a recipe and problem-based mini-projects for learning in order to increase the experiences of students in chemistry laboratory applications. Problem-based mini-projects for learning positively affected students' attendance to the course and their spirits, compared to previous years. In the study conducted by Kelly and Finlayson (2007), they used the PBL in the undergraduate level general chemistry laboratory. As a result of the study, they observed that students developed their application, transferable and cooperative working skills and increased their scientific and theoretical comprehension. Yadav et al. (2007) determined that trainers at universities and high schools expressed positive opinions about the CBL method and they stated that the method would increase students' learning, develop their critical thinking skills and encourage their active attendance to the course. Horzum and Alper (2006) concluded that the CBL applied in science course concerning environmental pollution was effective upon increasing the achievements of students.

As a result of their study; Dori, Tal, and Tsaushu (2003) determined that the CBL applied in biotechnology course concerning agricultural developments, production of insulin out of wine, genetic identity and change of genetic features increased the comprehension and knowledge of students, developed their metacognitive thinking skills and caused them to find the subjects interesting and convenient. Schwartz-Bloom and Halpin (2003) concluded that the usages of interesting science-related topics related with everyday life in the courses of biology and chemistry could be effective in increasing students' achievements and performances.

Flynn and Klein (2001) concluded that CBL method applied in the course of chemistry increased students' performances and motivations. Carder, Willingham, and Bibb (2001) used the case-based problem-based learning method in the fields of chemistry and medicine in their research. As a result of the research, they determined that small case studies being developed in the fields of chemistry and medicine enabled students to use library skills in solving problems and comprehend the importance of knowledge literacy, which is the basis of lifelong learning.

Ram (1999) used the PBL in the chemistry laboratory concerning water quality analyses. In his study, a real-life scenario enabled students to conduct analyses like fecal coliform, hardness in water, biochemical oxygen need and dissolved oxygen need. As a result of the study, it was determined that the PBL increased the motivation of students and developed their skills of solving problems, making investigations on their own, reaching new information and developing hypotheses for solving problems.

Herrier, Jackson, and Consroe (1997) examined the effect of case studies based on PBL on the undergraduate students' understanding the topics in the courses of pharmacology and medical chemistry. It was determined that case studies increased students' understanding and developed defining the problem, clinical reasoning and self-learning skills. Kesner, Hofstein, and Ben-Zvi (1997) concluded that case studies provided for the undergraduate students to see the relation between chemistry topics and daily life and developed students' positive attitudes towards the course of chemistry.

Studies being conducted in line with the aforementioned active learning approaches explicitly involve positive results, which suggest that the courses are interesting and they increase the success, motivation, attitudes, and cooperative working skills of students. According to the data of the relevant literature, it is thought that it would be efficient to use the CBL, which is supported by daily life problems, in the applications of the Analytical Chemistry Laboratory course. Undergraduate program of Chemistry Teaching involves students' ability of realizing complex formation titrations, interpreting titration types, making quantitative calculations and evaluating the calculation errors by statistical analysis data within the scope of the Analytical Chemistry Laboratory course. If students practically get this knowledge by solving daily life problems, they might acquire metacognitive thinking skills and increase their achievement, motivation and attitudes. $\mathrm{CBL}$ method would have a positive effect upon the process of learning only through having a case study concerning the $\mathrm{CBL}$ application related with daily life, an interesting scenario and an efficient material. In this context, views of students about the CBL, case study and the developed material are thought to be important. This study is important as it is among the limited number of studies using the CBL concerning "hardness determination in water via EDTA", which is an applica- 
tion of complex formation titrations, and it would pave the way for developing an efficient material on this issue.

The problem statement of the study is; "What are the views of $2^{\text {nd }}, 4^{\text {th }}$ and $5^{\text {th }}$ grade pre-service student teachers (ages between 20-23 years-old) studying Chemistry Teaching about the CBL, developed material and case study concerning 'hardness determination in water via EDTA' in the Analytical Chemistry Laboratory course?".

\section{Method}

The study was a descriptive research design. Descriptive research involves gathering data that describe events and then organizes, tabulates, depicts, and describes the data collection (Glass \& Hopkins, 1984). It was a qualitative study because it was aimed to determine students' views about the CBL, developed material and case study concerning 'hardness determination in water via EDTA.

\section{The Sample}

The sample of this descriptive study consists of $2^{\text {nd }}, 4^{\text {th }}$ and $5^{\text {th }}$ grade pre-service teachers $(n=23)$ (ages between 20-23 years-old) studying Chemistry Teaching at a university in Izmir, Turkey. All students from different grade levels were the students studying at the relevant department during the spring term of the education year of 2015-2016. The views of these students who were volunteered to participate in this study were taken (Christensen, Johnson, \&Turner, 2015; Taber, 2014). Students were primarily informed about the CBL method. After that, case study was given to each of the students and students were separated to the groups composed of two students. These groups were discussed on the case study, developed material's name, applicability and experimental procedure design by using brainstorming technique. Finally, all students were reported their views individually in written form.

\section{Data Collection Tools}

\section{Structured Interview Form}

Being prepared based on the opinions of two analytical chemistry laboratory and pedagogical experts and containing 12 open-ended questions aimed at determining the views of students about the method, material and the case study; structured interview form was used in the study (See Appendix 1). Among the open-ended questions; the questions between 1-3 were prepared via the CBL method; 4-8 were related with the material (refers to the whole CBL) and 9-10 case study. The questions between $11^{\text {th }}$ and $12^{\text {th }}$ were prepared for receiving the recommendations of students concerning a different scenario and a different material design from the CBL method on the aforementioned subject.

\section{Data Analysis}

The questions in the structured interview form that was used in the study were analyzed via content analysis, which is among qualitative analysis techniques. Reliability of the content analysis was provided by separating the acquired data into different categories by two analytical chemistry laboratory and pedagogical experts and calculating the average agreement percentage. The coding consistency of the categories created separately by two researchers was examined and in the calculation of the agreement percentage; $\mathrm{P}=\mathrm{N}_{\mathrm{a}} \times 100 / \mathrm{N}_{\mathrm{a}}+\mathrm{N}_{d}$ formula $\left(\mathrm{N}_{\mathrm{a}}=\right.$ The Amount of Agreement, $\mathrm{N}_{d}=$ The Amount of Disagreement, $\mathrm{P}=$ The percentage of agreement) was used. Two researchers came together in order to try to resolve the disagreements and in accordance with the results of agreements; the average agreement percentage was found as 84\% (Birkimer, \&Brown, 1979; Graham, Milanowski, \& Miller, 2012; Kılıc, Elci, \& Alkan, 2012; Kıranlı, 2010).

In addition to the average agreement percentage, Cohen's kappa statistic, a form of correlation coefficient, was also used to test interrater reliability for two researchers. The importance of rater reliability represents the extent to which the data collected in the study are correct representations of the variables measured. The results of Cohen's kappa are interpreted as follows: values $\leq 0$ as indicating no agreement, $0.01-0.20$ as none to slight, $0.21-0.39$ as minimal agreement, 0.40-0.59 as weak agreement, $0.60-0.79$ as moderate agreement, $0.80-0.90$ as strong agreement and 0.90 -above as almost perfect agreement (Marston, 2010; McHugh, 2012). Calculation of Cohen's kappa was performed according to the following formula: $k=[\operatorname{Pr}(\mathrm{a})-\operatorname{Pr}(\mathrm{e})] /[1-\operatorname{Pr}(\mathrm{e})]$; where $\operatorname{Pr}(\mathrm{a})$ represents the actual observed agreement, and $\operatorname{Pr}(\mathrm{e})$ represents chance agreement (McHugh, 2012). The calculation of Cohen's kappa between two researchers in this study was given in Appendix 2. In this study, Cohen's kappa was found as 0.81 indicating strong agreement between two researchers.

\section{Formation of the Case-Based Learning Scenario}

In the study, a case titled "Acarel-2016: Don't Let the Colors Fade" was prepared in relation with daily life by using the relevant literature and receiving the opinions of two analytical chemistry laboratory and pedagogical experts in the 
Analytical Chemistry Laboratory course (Demir, Demirci, \& Usanmaz, 1984; Dokmeci, 2001; Gunduz, 1984, 1999; Lehninger, Nelson, \& Cox, 1993; MEB, 2012a, 2012b; Skoog, West, \&Holler, 1996; Tan \& Tuysuz, 2013; WebMD, 2009; Yappert \&DuPre, 1997) (See Appendix 3).Consisting of two parts; the scenario is related with a laborant named Acar, who worked on surface active substances in laundry detergents preventing the laundry colors from fading. The scenario was prepared based on the investigations of the laborant concerning how the EDTA compound was effective upon colors. This scenario was prepared for the purpose of enabling the students to determine hardness in different waters like tap water, spring water and distillate water via the titration method by using the EDTA compound. The scenario also involves parts like 'Did You Know That?' concerning the usage areas of the EDTA compound and its effects upon human health.

\section{First Section of Developed Scenario of CBL}

First section of the scenario aims to teach the students that EDTA is used in increasing the cleaner features of other active substances in detergents, shampoos and soaps and moderating the water by forming a complex with metal cations in waters like calcium and magnesium, as well as in diseases like hypercalcemia and chelation treatment of hypercalcemia, determining the temporary and permanent hardness in water via EDTA titration and also teach them the usage areas of EDTA.

\section{Second Section of Developed Scenario of CBL}

Second section of the scenario aims to enable the students to prepare a buffer solution, EDTA solution and an indicator solution and carry out titration experiments in tap water, spring water and distillate water samples, determine the titration type and environment conditions to be considered in titration, calculate the titration result in three different samples, record the hardness degrees as ppm and learn the reliability and statistical analysis of the data. Besides, the section 'Did You Know That?' given at the end of the case study aims to inform the students about the usage areas of EDTA and its effects upon human health.

\section{Theoretical Knowledge about Developed Material for Instructors}

\section{The Information about EDTA and Hardness Determination in Water}

EDTA (Ethylene diamine tetra acetic acid) is a chemical substance which forms chelates with metals such as chromium, iron, lead, mercury, copper, aluminum, nickel, zinc, calcium, cobalt, manganese and magnesium and minerals and holds and binds the relevant metals and minerals. This substance is a six-fold ligand and since it gives rise to water-soluble, intact complexes with almost all cations, EDTA solutions are especially valuable as titrant. For this reason, it is widely used in complexation titrations. Due to the complexity of the health-threatening metals in the body with EDTA, there can be no side effects on the body and these metals can be removed from the body (Demir, Demirci, \& Usanmaz, 1984; Gunduz, 1984, 1999; Skoog, West, \& Holler, 1996; WebMd, 2009; Yappert \&DuPre, 1997).

\section{The Usage Areas of EDTA}

EDTA is a prescription medication which is injected intravenously or intramuscularly. It is used in lead poisoning and brain injury treatment. In addition, EDTA injected intravenously is used in the treatment of radioactive metal poisoning such as plutonium, thorium, uranium and strontium; in removing copper from the body in Wilson's disease; in the treatments of high levels of calcium, irregular heart rhythm, atherosclerosis, chest pain, high blood pressure, high cholesterol and circulatory disturbance. It is also used in eye drops to reduce high calcium levels accumulated in the eyes and in the treatment of skin irritation caused by metals such as chromium, nickel and copper. EDTA, which forms chelate with iron, is used in order to provide stability in cereal and cereal products and EDTA, chelating with calcium and sodium, is used to preserve the color, flavor and taste of the food. It is used in shampoos, liquid soaps, agricultural chemical sprayers, contact lens cleaners, cosmetic products and test tubes where the blood samples are collected in medicinal products (Lehninger, Nelson, \& Cox, 1993).

EDTA is also commonly used in the determination of water hardness. Total hardness in the water consists of temporary and permanent hardnesses. Water in natural sources is gained acidic property by taking carbon dioxide $\left(\mathrm{CO}_{2}\right)$ from the air. Such a water sample is converted into hard water when it makes contact with the rocks consisting of the salts of the ions of magnesium $\left(\mathrm{Mg}^{2+}\right)$ and the ions of calcium $\left(\mathrm{Ca}^{2+}\right)$ by dissolving these salts in their contents. Temporary hardness is derived from calcium and magnesium carbonates and bicarbonates and it cannot be removed by boiling this water sample. The salts of magnesium bicarbonate $\left(\mathrm{Mg}\left(\mathrm{HCO}_{3}\right)_{2}\right)$ and calcium bicarbonate $\left(\mathrm{Ca}\left(\mathrm{HCO}_{3}\right)_{2}\right)$ forming the temporary hardness are converted into the compounds of calcium carbonate $\left(\mathrm{CaCO}_{3}\right)$ and magnesium hydroxide $\left(\mathrm{Mg}(\mathrm{OH})_{2}\right)$ by heating. These two compounds precipitate and separate from the water: 


$$
\begin{gathered}
\mathrm{Ca}\left(\mathrm{HCO}_{3}\right)_{2(s)} \stackrel{\text { heating }}{\longrightarrow} \mathrm{CaCO}_{3(\mathrm{~s})}+\mathrm{H}_{2} \mathrm{O}_{(\mathrm{aq})}+\mathrm{CO}_{2(\mathrm{~g})} \\
\mathrm{Mg}\left(\mathrm{HCO}_{3}\right)_{2(\mathrm{~s})} \stackrel{\text { heating }}{\longrightarrow} \mathrm{Mg}(\mathrm{OH})_{2(\mathrm{~s})}+\mathrm{CO}_{2(\mathrm{~g})}
\end{gathered}
$$

The permanent hardness is formed by the combination of the ions calcium and magnesium with the ions of chloride, nitrate, sulfate, silicate and phosphate and this kind of hardness cannot be removed by boiling the water (Demir, Demirci, \& Usanmaz, 1984; Dokmeci, 2001; Gunduz, 1984, 1999; MEB, 2012a, 2012b; Skoog, West, \& Holler, 1996; Tan \&Tuysuz, 2013; WebMd, 2009; Yappert \&DuPre, 1997).

\section{The Experimental Procedure}

EDTA is an organic acid which can give four hydrogen ions to the water. Its formula can be shown as $\mathrm{H}_{4} \mathrm{Y}$. In complex formation titrations, the water-soluble sodium salt of EDTA, $\mathrm{Na}_{2} \mathrm{H}_{2} \mathrm{Y}_{2} 2 \mathrm{H}_{2} \mathrm{O}$ (disodium salt of EDTA) is used. This salt is used as the primer standard substance. The ions such as calcium $\left(\mathrm{Ca}^{2+}\right)$ and magnesium $\left(\mathrm{Mg}^{2+}\right)$, which have very small complex formation constants, are titrated with EDTA solution in a basic medium. Due to the pH dependence of the complex formation, the titration medium has to be buffered to a certain $\mathrm{pH}$. In the complex formation titrations with EDTA solution, it is also important the indicator solution to be used as well as the $\mathrm{pH}$ of the medium. In this kind of titration, organic dyes which make colored complexes with metal ions are used and Eriochrome Black T is a widely used indicator (Demir, Demirci, \& Usanmaz, 1984; Dokmeci, 2001; Gunduz, 1984, 1999; MEB, 2012a, 2012b; Skoog, West, \& Holler, 1996; Tan \&Tuysuz, 2013; WebMd, 2009; Yappert \&DuPre, 1997).

The preparation of the Eriochrome Black T indicator: The dye of Eriochrome Black T is the sodium salt of 1- (1-hydroxy-2-naphthylazo) -5-nitro-2-naphthol-4-sulfonic acid. It is scaled of 20 grams solid of sodium chloride ( $\mathrm{NaCl}$ ). It is pulverized in the mortar. Then, 0.1 gram of Eriochrome Black $\mathrm{T}$ is added upon it and they are thoroughly mixed by grinding in the mortar. It is stored in a sealed bottle. For a titration, 30-40 mg of this mixture is sufficient.

The preparation of 0.01 M EDTA solution: 3.723 grams of EDTA disodium salt $\left(M_{A}=372.24 \mathrm{~g} / \mathrm{mol}\right)$ is precisely weighed and placed into one-liter volumetric flask. Firstly, it dissolves in a small amount of distilled water, and then it is completed into one liter:

$$
\begin{gathered}
\mathrm{n}=\frac{\mathrm{m}}{\mathrm{M}_{\mathrm{A}}}=\frac{3.723 \mathrm{grams}}{372.24 \frac{\mathrm{grams}}{\mathrm{moles}}}=0.01 \mathrm{~mol}, \quad \mathrm{M}=\frac{\mathrm{n}}{\mathrm{V}}=\frac{0.01 \mathrm{moles}}{1 \mathrm{liter}}=0.01 \mathrm{~mol} / \mathrm{L} \\
\mathrm{N}=\mathrm{M} \times \text { Effect Valence }=0.01 \times 2=0.02 \mathrm{Normal}
\end{gathered}
$$

The preparation of buffer solution: In this titration medium; the $\mathrm{pH}$ should be around 10.0. For this reason, a basic buffer solution is used. One $100 \mathrm{~mL}$ of volumetric flask is taken and it is put some water in. Then, it is added that 6.75 grams solid of ammonium chloride $\left(\mathrm{NH}_{4} \mathrm{Cl}\right)$ into the volumetric flask. And then, $58 \mathrm{~mL}$ of the concentrated ammonia $\left(\mathrm{NH}_{3}\right)$ solution is added. It is filled with pure water up to level line of the flask.

The application of hardness determination with EDTA solution: It is taken $50 \mathrm{~mL}$ of water which is determined the hardness and put in a $250 \mathrm{~mL}$ Erlenmeyer flask. It is added Eriochrome Black T indicator and $1 \mathrm{~mL}$ of the buffer solution into the flask. This solution is titrated with EDTA until the color of red is turned into the sky blue. Total hardness in the water is calculated as ppm ( $\mathrm{mg} / \mathrm{L}) \mathrm{CaCO}_{3}\left(\mathrm{M}_{\mathrm{A}}=100\right.$ grams/moles):

$$
\text { Total Hardness (ppm CaCO } \left.\mathrm{Ca}_{3}\right)=\frac{\mathrm{N}_{\mathrm{EDTA}} \times \mathrm{V}_{\mathrm{EDTA}} \times\left(\mathrm{M}_{\mathrm{A}\left(\mathrm{CaCO}_{3}\right) / 2}\right) \times 1000}{\text { The Amount of Sample }(\mathrm{mL})}
$$

Hardness is also expressed as degrees of hardness in Clark (English) Degrees, French or German Degrees. Interconversion can be made by using the appropriate conversion factors as follows: converting $\mathrm{mg} \mathrm{CaCO}_{3} / \mathrm{mL}$ to Clark Degrees is the multiplication by 0.07; converting $\mathrm{mg} \mathrm{CaCO} / 3 \mathrm{~mL}$ to French Degrees is the multiplication by 0.1 and converting $\mathrm{mg}$ $\mathrm{CaCO}_{3} / \mathrm{mL}$ to German Degrees is the multiplication by 0.056 (United Utilities, Accessed June 5, 2017). 


\section{Results and Discussion}

\section{Results concerning the content analysis of structured interview form}

The students discussed and brainstormed the developed material, case study, the CBL method, the application and the experimental procedure processes. They discussed on the case study, material's applicability and difficulty, application process and experimental procedure design. Then, structured interview form was applied to them. The data obtained from the form were analyzed by the content analysis. The results were presented in terms of the method, material and case study.

\section{Results concerning CBL method, group work and the application process}

Table 1 shows the positive and negative views of students about the CBL method, group work and the application process:

Table 1. Positive and Negative Views of Students about the CBL Method, Group Work and the Application Process

\begin{tabular}{|c|c|c|c|c|c|}
\hline \multicolumn{3}{|l|}{ Positive Views } & \multicolumn{3}{|l|}{ Negative Views } \\
\hline Main Theme-1: CBL Method & $f$ & $\%$ & Main Theme-1: CBL Method & $f$ & $\%$ \\
\hline Sub-themes: & 79 & 81.44 & Sub-themes: & 18 & 18.56 \\
\hline Remembered easily & 16 & 20.25 & Time-consuming & 8 & 44.44 \\
\hline Related with daily life & 12 & 15.19 & Tiring & 2 & 11.10 \\
\hline Entertaining & 12 & 15.19 & Difficulty of finding resources in the research & 2 & 11.10 \\
\hline Comprehensible/Instructive & 8 & 10.13 & No preliminary information & 1 & 5.56 \\
\hline Development of metacognitive skills & 8 & 10.13 & Difficulty of expressing opinions & 1 & 5.56 \\
\hline Convenient & 7 & 8.85 & Not comprehensible / Instructive & 1 & 5.56 \\
\hline Interesting/ Thought-provoking & 5 & 6.33 & Unusual & 1 & 5.56 \\
\hline Active participation & 2 & 2.53 & Having distractibility & 1 & 5.56 \\
\hline Having visuality & 2 & 2.53 & Disconnection in incidents & 1 & 5.56 \\
\hline Research-provoking & 2 & 2.53 & & & \\
\hline Motivating & 2 & 2.53 & & & \\
\hline Observation & 1 & 1.27 & & & \\
\hline Communication skill & 1 & 1.27 & & & \\
\hline Opportunity of applying & 1 & 1.27 & & & \\
\hline Main Theme-2: Difficulty of application & $\mathbf{f}$ & $\%$ & Main Theme-2: Difficulty of application & f & $\%$ \\
\hline Sub-themes: & 21 & 84.00 & Sub-themes: & 4 & 16.00 \\
\hline Having no compulsion & 16 & 76.20 & Encountering the concepts for the first time & 2 & 50.00 \\
\hline Having information exchange & 1 & 4.76 & Time-consuming & 1 & 25.00 \\
\hline Self-learning & 1 & 4.76 & Difficulty of solving incoherent parts & 1 & 25.00 \\
\hline Teacher's guidance & 1 & 4.76 & & & \\
\hline Interesting/ Thought-provoking & 1 & 4.76 & & & \\
\hline Successful & 1 & 4.76 & & & \\
\hline Main Theme-3: Group work & f & $\%$ & Main Theme-3: Group work & $\mathbf{f}$ & $\%$ \\
\hline Sub-themes: & 32 & 60.38 & Sub-themes: & 21 & 39.62 \\
\hline Finding a solution in a short time & 10 & 31.24 & Conflict of opinions & 8 & 38.10 \\
\hline Cooperative work & 8 & 25.00 & Time-consuming & 4 & 19.05 \\
\hline Communication skill & 4 & 12.50 & Passiveness of some friends & 4 & 19.05 \\
\hline Comprehensible/ Instructive & 4 & 12.50 & Digressing & 2 & 9.52 \\
\hline Discussion environment & 4 & 12.50 & Lack of communication & 1 & 4.76 \\
\hline Remembered easily & 1 & 3.13 & Noisy environment & 1 & 4.76 \\
\hline Entertaining & 1 & 3.13 & Encountering the concepts for the first time & 1 & 4.76 \\
\hline Total (Positive Views) & 132 & 75.43 & Total (Negative Views) & 43 & 24.57 \\
\hline
\end{tabular}

As seen in Table 1; the students have more positive views (75.43\%) about the CBL method, application process and group work than negative views (24.57\%). The students define the method with positive expressions like; remembered easily, related with daily life, entertaining, comprehensible/instructive, good for developing metacognitive skills, convenient, interesting, encouraging for active participation, motivating and research-provoking. This finding is also supported by some studies in literature (Ayyıldız \&Tarhan, 2012; Carder, Willingham, \&Bibb, 2001; Ekici, 2016; Ertmer, Newby, \& MacDougall, 1999; Harman et al.2015; Kantar \& Massouh, 2015; Kelly \& Finlayson, 2007; Kerr \& Yan, 2016; Kılınc Alpat, Uyulgan, Ozbayrak, \& Alpat, 2011; Kocak \&Onen, 2012; Tarkın, 2014; Pintrich \&Schunk, 2002; Pintrich, Smith, Garcia, 
\& McKeachie, 1991; Ram, 1999; Thistlethwaite et al., 2012; Williams, 2006; Yoo\& Park, 2014). Their negative views about the method include having a difficulty in finding resources in the research and expressing opinions due to lack of preliminary information, which would make the method time-consuming, tiring and unusual (Ekici, 2016; Tarkın, 2014).

However, teachers play a role as guides and education leaders in the CBL method. In this context, education leaders enable students to discuss, offer solutions, use convenient resources concerning the subject and participate actively. These negative statements are considered natural as students had encountered the method for the first time (Tarkın, 2014). One of the students recommended the topic to be embraced teacher-centered:

"It would be better if the topic was embraced teacher-centered." (S17)

While majority of students expressed positive views about the CBL method like teachers' leadership, self-learning, mutual information sharing and having no difficulty in application due to the intriguing and successful case study; only four students expressed negative views and they believed that the method would be time-consuming due to new concepts and difficulty of solving incoherent parts. In his study; Tarkın (2014) concluded that majority of students expressed positive opinions about the CBL method as they had no difficulty, whereas some of them expressed negative opinions as they had difficulties in group work, interpretation of case studies and question-answer sections. In general, majority of students expressed positive views as they could cooperate in group work, exchange information, communicate, find a solution by creating a discussion environment in a short time and have fun. Their negative views about group work involved conflict of opinions, lack of communication, passiveness of some friends, digressing, noisy environment and the possibility of being time-consuming due to encountering new concepts. In his study; Ekici (2016) concluded that students found group work in the CBL method time-consuming and some of them expressed negative opinions about passiveness. In the study of Han et al. (2015), it was determined that the CBL method increased students' comprehension, decreased their memorization-based learning, enabled them to acquire independent thinking and social skills and save both time and labor force.

\section{Results concerning the material}

Table 2 shows positive and negative views of students about material's name, advantages and disadvantages, thought-provoking aspect and deficiency. As is seen in Table 2, students have more positive views ( $85.57 \%$ ) about material's name, advantages and disadvantages, thought-provoking aspect and deficiency than negative views (14.43\%):

Table 2. Positive and Negative Views about Material's Name, Advantages and Disadvantages, Thought-provoking Aspect and Deficiency

\begin{tabular}{|c|c|c|c|c|c|}
\hline \multicolumn{3}{|l|}{ Positive Views } & \multicolumn{3}{|l|}{ Negative Views } \\
\hline Main Theme-4: Material's name & $f$ & $\%$ & Main Theme-4: Material's name & $f$ & $\%$ \\
\hline Sub-themes: & 32 & 96.97 & Sub-themes: & 1 & 3.03 \\
\hline Convenient & 17 & 53.13 & Giving his name & 1 & 100.0 \\
\hline Interesting & 14 & 43.75 & & & \\
\hline Entertaining & 1 & 3.12 & & & \\
\hline Main Theme-5: Material's advantages & $f$ & $\%$ & Main Theme-5: Material's advantages & $\mathbf{f}$ & $\%$ \\
\hline Sub-themes: & 28 & 71.80 & Sub-themes: & 11 & 28.20 \\
\hline Comprehensible/ Instructive & 8 & 28.58 & Time-consuming & 7 & 63.64 \\
\hline Definitely advantageous & 6 & 21.43 & Too many questions & 2 & 18.18 \\
\hline Interesting/ Thought-provoking & 6 & 21.43 & Difficult of teaching & 2 & 18.18 \\
\hline Remembered easily & 2 & 7.14 & & & \\
\hline Related with daily life & 2 & 7.14 & & & \\
\hline Entertaining & 2 & 7.14 & & & \\
\hline Cooperative learning & 1 & 3.57 & & & \\
\hline Practical learning & 1 & 3.57 & & & \\
\hline $\begin{array}{l}\text { Main Theme-6: Material's thought-provo- } \\
\text { king aspect and deficiency }\end{array}$ & $f$ & $\%$ & $\begin{array}{l}\text { Main Theme-3: Material's thought-provoking } \\
\text { aspect and deficiency }\end{array}$ & $f$ & $\%$ \\
\hline Sub-themes: & 23 & 92.00 & Sub-themes: & 2 & 8.00 \\
\hline Thought-provoking & 8 & 34.78 & No thought-provoking & 2 & 100.0 \\
\hline Sufficient & 7 & 30.44 & & & \\
\hline Convenient & 4 & 17.38 & & & \\
\hline Comprehensible/ Instructive & 2 & 8.70 & & & \\
\hline A rich material & 2 & 8.70 & & & \\
\hline Total (Positive Views) & 83 & 85.57 & Total (Negative Views) & 14 & 14.43 \\
\hline
\end{tabular}


Students expressed positive views about material's name like convenient, interesting and entertaining. Only one student expressed negative view about material's name since the laborant had given his name to the laundry detergent:

"I think he is an egoist person and it is not genuine to give his surname to the material." (S10)

Two students recommended material's name to be 'Harmony of Colors'(S18) and that 'It could be a little more mysterious' (S20).

The majority of students expressed positive views about the material like comprehensible, instructive, definitely advantageous, interesting, remembered easily, related with daily life, entertaining, thought-provoking, convenient and that the material could enable them to work in cooperation and conduct applications. Students' negative views about the material involved being time-consuming, having too many questions and difficulty of teaching. Besides, only one student expressed negative view about the thought-provoking aspect of the material. McNaught et al. (2005) concluded that the CBL applied in physics course concerning surface analysis increased students' motivation toward the course on one hand and caused them to become reluctant in taking learning responsibilities on the other. This finding supports the necessity for the material developed in the CBL method to consider the expectations and beliefs of students. In our study, only one student did not find the material thought-provoking, which shows that it is not convenient for student's expectations. Majority of students had positive views about the material and suggested that it was a sufficient and rich material without any deficiency:

"The part 'Did You Know That?' enriches the material." (S7)

Besides, some students made suggestions concerning how to develop the material, such as being clearer and more comprehensible, increasing the visuality and using other examples:

"It could be clearer and more comprehensible." (S4) (S5) (S6)

"It could have a visuality." (S12)

"There could be other examples." (S17)

All students expressed positive views about the usage purpose, guidance and recollectiveness of the material (Table 3):

Table 3. Positive Views about the Usage Purpose, Guidance and Recollectiveness of the Material

\begin{tabular}{|c|c|c|c|c|c|}
\hline \multicolumn{6}{|l|}{ Positive Views } \\
\hline Main Theme-7: Material's usage purpose & f & $\%$ & Main Theme-8: Guidance & f & $\%$ \\
\hline Sub-themes: & 22 & 100.0 & Sub-themes: & 49 & 100.0 \\
\hline Convenient & 9 & 40.91 & Guiding & 18 & 36.74 \\
\hline Remembered easily & 6 & 27.27 & Entertaining & 11 & 22.45 \\
\hline Related with daily life & 2 & 9.09 & Research-provoking & 10 & 20.41 \\
\hline Helpful for experiments & 2 & 9.09 & Sufficient & 5 & 10.20 \\
\hline Productive & 2 & 9.09 & Comprehensible/ Instructive & 3 & 6.12 \\
\hline Comprehensible/ Instructive & 1 & 4.55 & Interesting/ Thought-provoking & 2 & 4.08 \\
\hline Main Theme-7: Recollectiveness & $f$ & $\%$ & & & \\
\hline Sub-themes: & 29 & 100.0 & & & \\
\hline $\begin{array}{l}\text { Negative effect of EDTA compound and } \\
\text { EDTA upon human health and environment }\end{array}$ & 10 & 34.48 & & & \\
\hline Usage areas of EDTA & 6 & 20.69 & & & \\
\hline Hardness determination in water & 4 & 13.79 & & & \\
\hline Color retention & 3 & 10.35 & & & \\
\hline All subjects & 3 & 10.35 & & & \\
\hline Hypercalcemia & 2 & 6.90 & & & \\
\hline Chelation treatment & 1 & 3.44 & & & \\
\hline Total (Positive Views) & 100 & 100.0 & & & \\
\hline
\end{tabular}

As seen in Table 3, all students expressed positive views about the material and stated that it was fit for usage purpose, remembered easily, helpful for experiments, productive, comprehensible, instructive, related with daily life, guiding for the topic and research, sufficient and interesting. They also expressed positive views about making investigations and finding it entertaining. In his study, Cheng (1995) stated that the CBL method applied in environmental chemistry course concerning water pollution encouraged students to investigate. In this study; students expressed positive opinions about the negative effect of EDTA upon human health and environment, usage areas of EDTA, its usability in 
laundry detergents for color retention, chelation treatment, hardness determination in water, hypercalcemia and they stated that all subjects concerning the material content could be remembered easily.

\section{Results concerning the case study}

All students expressed positive views about the case study and suggested that it was related with daily life, interesting, comprehensible, instructive and majority of students stated that the case study had no part to be added or excluded and it was sufficient (Table 4):

Table 4. Positive Views about the Case-Study

\begin{tabular}{|c|c|c|c|c|c|}
\hline \multicolumn{6}{|l|}{ Positive Views } \\
\hline Main Theme-9: Case study & f & $\%$ & $\begin{array}{l}\text { Main Theme-10: Parts to be added to or } \\
\text { excluded from the case study }\end{array}$ & f & $\%$ \\
\hline Sub-themes: & 43 & 100.0 & Sub-themes: & 18 & 100.0 \\
\hline Related with daily life & 23 & 53.49 & Sufficient & 18 & 100.0 \\
\hline Interesting/ Thought-provoking & 19 & 44.19 & & & \\
\hline Comprehensible/ Instructive & 1 & 2.32 & & & \\
\hline Total (Positive Views) & 61 & 100.0 & & & \\
\hline
\end{tabular}

Only three students suggested that the case study could be enriched by adding other case studies and excessive work of the laborant could be excluded from the case study:

"It could be enriched by other samples." (S4)

"Excessive work of the person could be excluded." (S6)

"A few more case studies could be added." (S17)

Examining the positive and negative views of students about the method, material and the case study in general; it is seen that students have higher rates of positive views (86.84\%) than negative views (13.16\%) (Table 5):

Table 5. Total Content Analysis Concerning the Method, Material and the Case-Study

\begin{tabular}{lcccc}
\hline & \multicolumn{2}{c}{ Positive Views } & \multicolumn{2}{c}{ Negative Views } \\
\hline Main Themes & $\mathrm{f}$ & $\%$ & $\mathrm{f}$ & $\%$ \\
\hline CBL Method & 132 & 75.43 & 43 & 24.57 \\
Material & 183 & 92.89 & 14 & 7.11 \\
Case Study & 61 & 100.0 & --- & 0.0 \\
\hline Total & 376 & 86.84 & 57 & 13.16 \\
\hline
\end{tabular}

This finding shows that students have positive views about the CBL method, the developed material and the case study and that the method could be applied in the Analytical Chemistry Laboratory course concerning "hardness determination in water via EDTA".

Regarding the question, "What would your scenario on hardness determination in water look like?"; seven students stated that they could write a scenario similar to the developed case study, whereas other students made different scenario suggestions concerning calcareous and bad tap water, calcified teapots, broken washing machines, story of the person investigating the ocean waters, use of EDTA in cosmetic products, shampoos and blood analysis, stream water in villages and investigation of a chemist:

"A scenario based on calcareous and bad tap water" (S3)

"A case study based on the usage of EDTA in the blood analysis" (S6)

"A text arousing interest in hardness in water" (S11)

"We could bring a calcified teapot into the classroom or let's say Mrs. Ayse has a broken washing machine or dishwasher." (S12)

"I would ground on the story of a scientist investigating tap waters." (S13)

"I would tell the story of a person investigating the ocean waters." (S14)

"I would develop a scenario based on tap waters." (S15)

"A case study based on tap waters." (S16) 
"A case study probably associating EDTA with cosmetic products" (S17)

"The plotline could be as follows: the water we used to drink from the stream in our village started to taste hard after some time and I started investigating the reason of that condition." (S18)

"It would be a case study concerning EDTA with shampoos"(S21)

"It would also aim the investigation of a chemist." (S23)

Regarding the question, "What kind of material would you design concerning this topic, except for the case study?"; five students stated that they could design the same material as the developed material, whereas other students made different suggestions concerning the material design such as displaying animations and documentaries, writing an article for the study, preparing a report on EDTA, trying other learning techniques, preparing a work scheme for hardness determination in water, conducting experiments and displaying videos, using project-based education or PBL and designing a karaoke on this topic:

"My material has been conducted on an animation, a documentary and an observable case." (S3)

"An article could be written on researches." (S4)

"I could prepare a report on EDTA as theoretical knowledge." (S5)

"Other techniques could also be investigated and tried." (S10)

"I would prepare a work scheme for removing hardness in water." (S11)

"We could organize an experiment, observation and maybe an excursion and make students prepare a project." (S13)

"We could conduct an experiment and a project." (S14)

"We could prepare an experiment or a video and use a project-based education method and all relevant materials." (S15)

"We could prepare a project homework and conduct PBL by developing a problem." (S16)

"I could design a karaoke on this topic." (S17)

"I would design an experiment." (S21)

\section{Conclusion}

The objective of this study is to examine students' views about case study, material and CBL method developed for 'hardness determination in water via EDTA solution' in the Analytical Chemistry Laboratory course. CBL is an active learning method that enables students to combine knowledge and concepts with real life conditions and bridges between theory and practice. This learning method emphasizes active participation of students, education leadership and use of real life conditions (Beaton, Dochy, \& Struyven, 2013). The literature also involves studies suggesting that the CBL method positively increases students' attitudes toward chemistry course (Cam \&Geban, 2011; Kerr \& Yan, 2016; Kesner, Hofstein, \& Ben-Zvi, 1997; Kılınc Alpat, Uyulgan, Ozbayrak, \& Alpat, 2011; Kocak \&Onen, 2012; McDonnell, O’Connor, \& Seery, 2007; Yalcınkaya, Boz, \& Erdur-Baker, 2012).

In relevant the literature, it is determined that there is limited number of studies concerning CBL and PBL-based case studies about water-related issues (Bholah, 2017; Cam \&Geban, 2011; Cheng, 1995; Kumar, 2017; Ram, 1999). When examining these studies, it was seen that using of the related active learning methods in education increased students' understanding, positive attitudes toward chemistry, motivation and developed problem solving, investigation, discussion skills and only one study of Cam and Geban (2011) implemented the CBL method concerning 'Water Hardness'. In their study, they concluded that CBL increased the students' positive attitudes toward chemistry course.

In this study, it is purposed to fill up this gap about this topic and developed a case study. According to students' views about this developed case study, it was concluded that this will be an effective tool for Analytical Chemistry Laboratory course for the undergraduate level students. Because in the study, the majority of students expressed positive views about the method and suggested that it was remembered easily, related with daily life and that the material and the case study were convenient, comprehensible, interesting, sufficient and instructive. They stated that the method could enable the development of metacognitive and communication skills and the material was guidance and helpful for experiments. For instance, Harman et al. (2015) concluded that CBL method prepares students for problems that they may encounter in professional practice in their study. In their research of Thistlethwaite et al. (2012), students stated that the CBL method enhanced their learning and motivation and it was entertaining. They also had negative views and suggested that the method was unusual, tiring and time-consuming. This finding was also supported by some studies in the literature (Ekici, 2016; Tarkın, 2014). While the literature data support the applicability of the CBL method; students' positive statements about the material and the case study support the applicability of the material developed in the aforementioned subject. 


\section{Implications}

It is suggested that the case study and the material developed in the study could be efficiently used in "hardness determination in water via EDTA" and supported by additional materials to be prepared according to the recommendations of students. It is thought that after the case study and the material to be developed in the next study are applied in the laboratory environment, the effect of CBL upon students' academic achievement, metacognitive skills and attitudes toward chemistry course could be examined.

\section{References}

Australian Education Council (1994). Science: A Curriculum Profile for Australian Schools. Melbourne: Curriculum Corporation.

Ayyıldız, Y., \& Tarhan, L. (2012). Effect of Case Studies on Primary School Teaching Students' Attitudes toward Chemistry Lesson. Hacettepe University Journal of Education, 43, 62-70.

Beaten, M., Dochy, F., \& Struyven, K. (2013). Enhancing Students' Approaches to Learning: The Added Value of Gradually Implementing Case-Based Learning. European Journal of Psychology of Education, 28(2), 315-336.

Belova, N., \& Eilks, I. (2015). Learning with and about Advertising in Chemistry Education with a Lesson Plan on Natural Cosmetics-A Case Study. Chemistry Education Research and Practice, 16(3), 578-588.

Bholah, R. (2017). Developing Problem-Based Learning Approaches to Water Education in Mauritius. In H. Lotz-Sisitka, O. Shumba, J. Lupele, \& D. Wilmot (Eds.), Schooling for Sustainable Development in Africa (Chap. 2, pp. 119-127). Switzerland: Springer International Publishing.

Birkimer, J.C., \& Brown, J.H. (1979). Back to Basics: Percentage Agreement Measures are Adequate, but there are Easier Ways. Journal of Applied Behavior Analysis, 12(4), 535-543.

Cam, A. (2009). Effectiveness of Case-Based Learning Instruction on Students' Understanding of Solubility Equilibrium Concepts. PhD diss., Middle East Technical University, Ankara.

Cam, A., \& Geban, Ö. (2011). Effectiveness of Case-Based Learning Instruction on Epistemological Beliefs and Attitudes toward Chemistry. Journal of Science Education and Technology, 20(1), 26-32.

Carder, L., Willingham, P., \& Bibb, D. (2001). Case-Based, Problem-Based Learning: Information Literacy for the Real World. Research Strategies, 18(3), 181-190.

Cheng, V.K.W. (1995). An Environmental Chemistry Curriculum Using Case Studies. Journal of Chemical Education, 72(6), 525-527.

Choi, I., \& Lee, K. (2009). Designing and Implementing a Case-Based Learning Environment for Enhancing III-structured Problem Solving: Classroom Management Problems for Prospective Teachers. Educational Technology Research and Development, 57(1), 99-129.

Christensen, L.B., Johnson, R.B., \& Turner, L.A. (2015). Research Methods: Design and Analysis. $2^{\text {nd }}$ ed. Ankara: Anı Yayıncllık.

Demir, M., Demirci, Ş., \& Usanmaz, A. (1984). Analytical and Industrial Chemistry Laboratory. Ankara: MEB Yayınları.

Dokmeci, i. (2001). Toxicology: Diagnosis and Treatment in Poisoning. $3^{\text {rd }}$ ed. Ankara: Nobel Tip Kitabevi.

Dori, Y.J., Tal, R.T., \& Tsaushu, M. (2003). Teaching Biotechnology through Case Studies-Can We Improve Higher Order Thinking Skills of Nonscience Majors?. Science Education, 87(6), 767-793.

Ekici, D.i. (2016). Examination of Pre-service Science Teachers' Activities Using Problem Based Learning Method. Educational Research and Reviews, 11(1), 37-47.

Ertmer, P.A., Newby, T.J., \& MacDougall, M. (1999). Students' Responses and Approaches to Case-Based Instruction: The Role of Reflective Self-Regulation. American Educational Research Journal, 33(3), 719-752.

Figueiredo, M., Esteves, L., Neves, J., \& Vicente, H. (2016). A Data Mining Approach to Study the Impact of the Methodology followed in Chemistry Lab Classes on the Weight Attributed by the Students to the Lab Work on Learning and Motivation. Chemistry Education Research and Practice, 17(1), 156-171.

Flynn, A.E., \& Klein, J.D. (2001). The Influence of Discussion Groups in a Case-Based Learning Environment. Educational Technology Research and Development, 49(3), 71-86.

Garnett, P.J., Garnett, P.J., \& Hackling, M.W. (1995). Refocusing the Chemistry Lab: A Case for Laboratory-Based Investigations. Australian Science Teachers Journal, 41(2), 26-32.

Glass, G. V., \& Hopkins, K. D. (1984). Statistical Methods in Education and Psychology. $2^{\text {nd }}$ ed. Englewood Cliffs, N. J.: Prentice-Hall.

Graham, M., Milanowski, A., \& Miller, J. (2012). Measuring and Promoting Inter-Rater Agreement of Teacher and Principal Performance Ratings. Center for Educator Compensation Reform, February, 1-33. doi: ED532068. Accessed 10 March 2016. http:// files.eric.ed.gov/fulltext/ED532068.pdf.

Gunduz, T. (1984). Quantitative Analysis Laboratory Manual. Ankara: Ankara Üniversitesi Fen Fakültesi Yayınları.

Gunduz, T. (1999). Qualitative Analysis Course Book. $6^{\text {th }}$ ed. Ankara: Gazi Kitabevi.

Han, X., Zhuang, Y., Pan, K., Zhang, M., An, L., Xu, G., \& Zhang, Y. (2015). Practice and Exploration of Teaching Reform of the Pharmaceutical Microbiology in Pharmaceutical Education. In H. Ding (Ed.), Proceedings of the 2015 International Conference on 
Food Hygiene, Agriculture and Animal Science (pp. 145). China: Wuhan, Hubei.

Harman, T., Bertrand, B., Greer, A., Pettus, A., Jennings, J., Wall-Bassett, E., \& Babatunde, O.T. (2015). Case-Based Learning Facilitates Critical Thinking in Undergraduate Nutrition Education: Students Describe the Big Picture. Journal of the Academy of Nutrition and Dietetics, 115(3), 378-388.

Harman, G., Cokelez, A., Dal, B., \& Alper, U. (2016). Pre-service Science Teachers' Views on Laboratory Applications in Science Education: The Effect of a two-semester course. Universal Journal of Educational Research, 4(1), 12-25.

Herrier, R.N., Jackson, T.R., \& Consroe, P.F. (1997). The Use of Student-Centered, Problem-Based, Clinical Case Discussions to Enhance Learning in Pharmacology and Medicinal Chemistry. American Journal of Pharmaceutical Education, 61, $441-446$.

Hofstein, A. (2004). The Laboratory in Chemistry Education: Thirty Years of Experience with Developments, Implementation and Research. Chemistry Education and Research Practice, 5(3), 247-264.

Horzum, M.B., \& Alper, A. (2006). The Effect of Case Based Learning Model, Cognitive Style and Gender to the Student Achievement in Science Courses. Ankara University Journal of Faculty of Educational Science, 39(2), 151-175.

Jansson, S., Söderström, H., Andersson, P.L., \& Nording, M.L. (2015). Implementation of Problem-Based Learning in Environmental Chemistry. Journal of Chemical Education, 92(12), 2080-2086.

Jarz, E.M., Kainz, G.A., \& Walpoth, G. (1997). Multimedia-based case studies in education: Design, development, and evaluation of multimedia-based case studies. Journal of Educational Multimedia and Hypermedia, 6(1), 23-46.

Kantar, L.D., \& Massouh, A. (2015). Case-Based Learning: What Traditional Curricula Fail to Teach? Nurse Education Today, 35(8), 8-14.

Kelly, O.C., \& Finlayson, O.E. (2007). Providing Solutions through Problem-Based Learning for the Undergraduate $1^{\text {st }}$ year Chemistry Laboratory. Chemistry Education Research and Practice, 8(3), 347-361.

Kerr, M.A., \& Yan, F. (2016). Incorporating Course-Based Undergraduate Research Experiences into Analytical Chemistry Laboratory Curricula. Journal of Chemical Education, 93(4), 658-662.

Kesner, M., Hofstein, A., \& Ben-Zvi, R. (1997). Student and Teacher Perceptions of Industrial Chemistry Case Studies. International Journal of Science Education, 19(6), 725-738.

Kılıc, S.D., Elci, A.N., \& Alkan, H. (2012). High School Students' Opinions about a Performance-Improving Learning Environment and Learning Activities and Performance Assessment. Journal of Research in Education and Teaching, 1(3), 1-7.

Kılınç Alpat, S., Uyulgan, M.A., Ozbayrak, Ö., \& Alpat, Ş. (2011). A Study on the Effect of Case Based Learning for Pre-service Science Teachers' Attitudes towards an Analytical Chemistry Laboratory Experiment. Journal of Buca Education Faculty, 30, 1-10.

Kıranlı, S. (2010). High Schools Principals' Administrator Behaviour Forms. Inonu University Journal of the Faculty of Education, 11(2), 229-250.

Kocak, C., \& Onen, A.S. (2012). Evaluation of Chemistry Topics within the Daily Life Concept. Hacettepe University Journal of Education, 42, 262-273.

Kumar, D.D. (2017). Analysis of an Interactive Technology Supported Problem-Based Learning STEM Project Using Selected Learning Sciences Interest Areas (SLSIA). International Journal of Education in Mathematics, Science and Technology, 5(1), 53-61.

Lehninger, A.L., Nelson, D.L., \& Cox, M.M. (1993). Principles of Biochemistry. New York: Worth Publications Inc.

Marks, R., Bertram, S., \& Eilks, I. (2008). Learning Chemistry and Beyond with a Lesson Plan on Potato Crisps, which follows a Socio-critical and Problem-oriented Approach to Chemistry Lessons: A Case Study. Chemistry Education Research and Practice, 9(3), 267-276.

Marston, L. (2010). Introductory Statistics for Health and Nursing Using SPSS. Thousand Oaks, California: Sage Publications.

McDonnell, C., O'Connor, C., \& Seery, M.K. (2007). Developing Practical Chemistry Skills by means of Student-Driven Problem Based Learning Mini-Projects. Chemistry Education Research and Practice, 8(2), 130-139.

McHugh, M.L. (2012). Interrater Reliability: The Kappa Statistic. Biochemia Medica, 22(3), 276-282.

McNaught, C., Lau, W.M., Lam, P., Hui, M.Y.Y., \& Au, P.C.T. (2005). The Dilemma of Case-Based Teaching and Learning in Science in Hong Kong: Students Need It, Want It, But May Not Value It. International Journal of Science Education, 27(9), 1017-1036.

Merseth, K. (1991). The Early History of Case-Based Instruction: Insights for Teacher Education Today. Journal of Teacher Education, 42(4), 243-249.

Milli Eğitim Bakanlığı [MEB]. 2012a. Food Technology: Drinking and Drinking Water Analysis (pp 1-38). Ankara.

Milli Eğitim Bakanlığı [MEB]. 2012b. Chemical Technology: Water Analysis (pp 1-57). Ankara.

Owens, J.E., Zimmerman, L.B., Gardner, M.A., \& Lowe, L.E. (2016). Analysis of Whiskey by Dispersive Liquid-Liquid Microextraction Coupled with Gas Chromatography/ Mass Spectrometry: An Upper Division Analytical Chemistry Experiment Guided by Green Chemistry. Journal of Chemical Education, 93(1): 186-192.

Pintrich, P.R., \& Schunk, D. (2002). Motivation in Education: Theory, Research and Applications. $2^{\text {nd }}$ ed. Upper Saddle, NJ: Prentice-Hall, Inc.

Pintrich, P.R., Smith, D.A.F., Garcia, T., \& McKeachie, W.J. (1991). A Manuel for the Use of the Motivated Strategies for Learning Questionnaire (MSLQ) (Report No.NCRIPTAL-91-B-004). Washington, DC: National Center for Research to Improve Postsecondary Teaching and Learning, Ann Arbor, MI.

|Kastamonu Eğitim Dergisi, 27(5), 2019| 
Ram, P. (1999). Problem-Based Learning in Undergraduate Education. Journal of Chemical Education, 76(8), 1122-1226.

Schwartz-Bloom, R.D., \& Halpin, M.J. (2003). Integrating Pharmacology Topics in High School Biology and Chemistry Classes Improves Performance. Journal of Research in Science Teaching, 40(9), 922-938.

Shiland, T.W. (1999). Constructivism: The Implications for Laboratory Work. Journal of Chemical Education, 76(1), 107.

Skoog, D.A., West, D.M., \& Holler, F.J. (1996). Fundamentals of Analytical Chemistry. $7^{\text {th }}$ ed. Saunders College Publications.

Taber, K.S. (2014). Ethical Considerations of Chemistry Education Research Involving 'Human Subjects'. Chemistry Education Research and Practice, 15(2), 109-113.

Tan, A.S.B., \& Tuysuz, M. (2013). The Use of Preservatives in Cosmetic Products and Their Efficiency Testing. ANKEM Journal, 27(2), 83-91.

Tarkın, A. (2014). Implementation of Case-Based Instruction on Electrochemistry at $11^{\text {th }}$ Grade Level. PhD diss., Middle East Technical University, Ankara.

Thistlethwaite, J.E., Davies, D., Ekeocha, S., Kidd, J.M., Macdougall, C., Matthews, P., Purkis, J., \& Clay, D. (2012). The Effectiveness of Case-Based Learning in Health Professional Education. A BEME Systematic Review: BEME Guide No.23. Medical Teacher, 34(6), 421-444.

United Utilities (2017). Water Hardness. Resource document. https://www.unitedutilities.com/globalassets/documents/pdf/waterhardnessfactsheet_acc16.pdf. Accessed 5 June 2017.

WebMD. (2009). EDTA: Uses, Side Effects, Interactions and Warnings. Resource document. http://www.webmd.com/vitamins-supplements/ingredientmono-1032-edta. aspx?activeingredientid=1032\&. Accessed 10 February 2016.

Williams, B. (2006). Qualitative Analysis of Undergraduate Paramedic Students' Perceptions of Using Case-Based Learning in an Online Learning Environment. Journal of Emergency Primary Health Care (JEPHC), 4(3), Article 990191.

Williams, D.P., Woodward, J.R., Symons, S.L., \& Davies, D.L. (2010). A Tiny Adventure: The introduction of Problem Based Learning in an Undergraduate Chemistry Course. Chemistry Education Research and Practice, 11(1), 33-42.

Woolnough, B.E., \& Allsop, T. (1985). Practical Work in Science. Cambridge: Cambridge University Press.

Yadav, A., Lundeberg, M., DeSchryver, M., Dirkin, K., Schiller, N.A., Maier, K., \& Herreid, C.F. (2007). Teaching Science with Case Studies: A National Survey of Faculty Perceptions of the Benefits and Challenges of Using Cases. The Journal of College Science Teaching, 37(1), 34-38.

Yalcınkaya, E., Boz, Y., \& Erdur-Baker, Ö. (2012). Is Case-Based Instruction Effective in Enhancing High School Students' Motivation Toward Chemistry? Science Education International, 23(2), 102-116.

Yappert, M.C., \& DuPre, D.B. (1997). Complexometric Titrations: Competition of Complexing Agents in the Determination of Water Hardness with EDTA. Journal of Chemical Education, 74(12), 1422.

Yoo, M.S., \& Park, J.H. (2014). Effect of Case-Based Learning on the Development of Graduate Nurses' Problem-Solving Ability. Nurse Education Today, 34(1), 47-51.

\section{Appendices}

\section{Appendix 1. Structured Interview Form}

- What do you think about teaching the course in this way? What are the positive/negative aspects of this method in your opinion? Please explain.

- Was there anything challenging you during the application? Did you encounter any difficulties?

- What are the positive/negative aspects of group work?

- Do you think the material has an interesting and appropriate name? What would you call it if it was up to you?

- Considering the advantages and disadvantages of the material, can you write down your positive and negative views about the material?

- Has the material caused you to have an opinion about how to determine hardness in water via EDTA? If you think it is deficient, how do you think this material could be advanced?

- What do you remember about the material? Is the material appropriate in terms of usage purpose?

- Has the material directed you toward hardness determination in water? Has it been entertaining to investigate?

- Is the case study interesting and related with daily life?

- Is there any part to be added to or excluded from the case study? If there is, please write down.

- What would your scenario on hardness determination in water look like? Please explain your views.

- What kind of material would you design concerning this topic, except for the case study? 
Appendix 2. The Calculation of Cohen's Kappa

For the CBL Method;

\begin{tabular}{rccc}
\hline & \multicolumn{3}{c}{ Researcher 1 } \\
\cline { 2 - 4 } & Positive Views & Negative Views & Row Marginals \\
\hline Researcher 2; Positive Views & 25 & 2 & 27 \\
Negative Views & 2 & 17 & 19 \\
\hline & 27 & 19 & 46
\end{tabular}

$$
\begin{gathered}
\operatorname{Pr}(\mathrm{a})=\text { Raw \% Agreement }=\frac{25+17}{46}=0.91 \\
\operatorname{Pr}(\mathrm{e})=\text { Expected Agreement }=\frac{\left(\frac{27 \times 27}{46}\right)+\left(\frac{19 \times 19}{46}\right)}{46}=0.52
\end{gathered}
$$

Kappa $=\frac{0.91-0.52}{1-0.52}=0.81$ indicating strong agreement between researcher 1 and 2 concerning the CBL method

\section{For the Material (The Whole CBL);}

\begin{tabular}{cccc}
\hline & \multicolumn{3}{c}{ Researcher 1 } \\
\cline { 2 - 4 } & Positive Views & Negative Views & Row Marginals \\
\hline Researcher 2; Positive Views & 33 & 0 & 33 \\
Negative Views & 2 & 5 & 7 \\
\hline
\end{tabular}

$$
\begin{gathered}
\operatorname{Pr}(\mathrm{a})=\text { Raw \% Agreement }=\frac{33+5}{40}=0.95 \\
\operatorname{Pr}(\mathrm{e})=\text { Expected Agreement }=\frac{\left(\frac{35 \times 33}{40}\right)+\left(\frac{5 \times 7}{40}\right)}{40}=0.74
\end{gathered}
$$

Kappa $=\frac{0.95-0.74}{1-0.74}=0.81$ indicating strong agreement between researcher 1 and 2 concerning the material (the whole CBL)

\section{For the Case Study;}

\begin{tabular}{rccc}
\hline & \multicolumn{3}{c}{ Researcher 1 } \\
\cline { 2 - 4 } & Positive Views & Negative Views & Row Marginals \\
\hline Researcher 2; Positive Views & 3 & 0 & 3 \\
Negative Views & 1 & 0 & 1 \\
& 4 & 0 & 4 \\
\hline
\end{tabular}

$$
\begin{gathered}
\operatorname{Pr}(\mathrm{a})=\text { Raw } \% \text { Agreement }=\frac{3+1}{4}=1.00 \\
\operatorname{Pr}(\mathrm{e})=\text { Expected Agreement }=\frac{\left(\frac{4 \times 3}{4}\right)+\left(\frac{0 \times 1}{4}\right)}{4}=0.75
\end{gathered}
$$

Kappa $=\frac{1.00-0.75}{1-0.75}=1.00$ indicating almost perfect agreement between researcher 1 and 2 concerning the case study

For the CBL Method, Material and Case Study;

Researcher 1

Positive Views Negative Views Row Marginals

| Kastamonu Eğitim Dergisi, 27(5), 2019| 


\begin{tabular}{rlll}
\hline Researcher 2; Positive Views & 61 & 2 & 63 \\
Negative Views & 5 & 22 & 27 \\
\hline & 66 & 24 & 90 \\
\hline
\end{tabular}

$$
\begin{gathered}
\operatorname{Pr}(\mathrm{a})=\text { Raw \% Agreement }=\frac{61+22}{90}=0.92 \\
\operatorname{Pr}(\mathrm{e})=\text { Expected Agreement }=\frac{\left(\frac{66 \times 63}{90}\right)+\left(\frac{24 \times 27}{90}\right)}{90}=0.59
\end{gathered}
$$

Kappa $=\frac{0.92-0.59}{1-0.59}=0.81$ indicating strong agreement between researcher 1 and 2 concerning the CBL method, material and case study

\section{Appendix 3. Case Study \\ ACAREL--2016: “DON'T LET THE COLORS FADE”}

\section{PART I}

Acar worked as a laborant in a private factory manufacturing laundry detergents in Izmir. He had been working on a more efficient subsidiary active substance preventing the laundry colors from fading. He had been working intensely for eight months. He had waited for a month to see the effect of each different subsidiary active substance used in detergents. However, his work had produced no efficient result so far. Thus, he continued his work with ambition. His friends told Acar to take a rest for a while and even take a vacation as they saw him extremely tired and exhausted every day. But Acar refused to go without finishing his almost completed work. He worked day and night in the laboratory, went out only for buying food and even ate quickly in the laboratory and sometimes ordered a take away not to interrupt his work. Even though he had recently felt too much bone pain, he associated that condition with his intense work tempo. He kept failing in his researches and experiments. One day, he decided to use ethylene diamine tetra acetic acid (EDTA), which is an efficient complexifier, as a subsidiary active substance in laundry detergent. He used a certain amount of sodium salt of ethylene diamine tetra acetic acid in laundry detergent. He sent that laundry detergent for experiment again. This time, he successfully concluded that the laundry detergent he had manufactured was more effective upon preventing the laundry colors from fading. He named his laundry detergent "Acarel". In order to make his research even more reliable, he wanted to examine the effect of Acarel upon fading colors also in different waters (like tap water, spring water, distillate water). However, his body failed to tolerate the increasing bone pain and he fainted in the laboratory. He was taken to the emergency service of the nearest hospital by his colleagues. The emergency doctor checked Acar's vital signs and immediately required a biochemical analysis. The results showed that Acar's blood calcium level was $14 \mathrm{mg} / \mathrm{dL}$ (normal level: 8.5-10.2 mg/dL) and that he had hypercalcemia. Acar was immediately given liquid isotonic sodium chloride for hydration treatment, some diuretic medicine and intravenous EDTA for chelation treatment.

\section{Questions:}

- How do you think the colors are prevented from fading in Acarel colors that contain EDTA as subsidiary active substance?

- Do you think the effect of EDTA would change in different waters (like tap water, spring water, distillate water)? How would it change?

- Do you think Acar's hypercalcemia was related with EDTA? Why?

- What do you think about the reason of using EDTA in the chelation treatment of hypercalcemia?

- How do you think hardness in water could be determined?

- What are the cations that cause hardness in water? What are the methods of removing these cations?

- Do you think hardness in water could be determined via EDTA? How?

- What are the usage areas of EDTA?

\section{PART II}

Laborant Ayse who was one of Acar's colleagues in the factory had felt really sorry for him and decided to complete Acar's analysis when he was still in the hospital. She prepared a buffer solution, EDTA solution and an indicator solution and started titration in all tap water, spring water and distillate water samples. Calculating the titration results of all three samples; she recorded the hardness degrees as ppm and conducted the statistical analyses of the data for their reliability.

\section{Questions:}

- What solutions do you think the Laborant Ayse used as buffer and indicator solutions? 
- What is the type of the titration applied by the Laborant Ayse? Please explain the principles of such titration and the environment conditions to be considered.

- How do you think the Laborant Ayse calculated the result of her titration experiment?

- How do you think the Laborant Ayse calculated the statistical reliability of the data she had acquired?

\section{DID YOU KNOW THAT?}

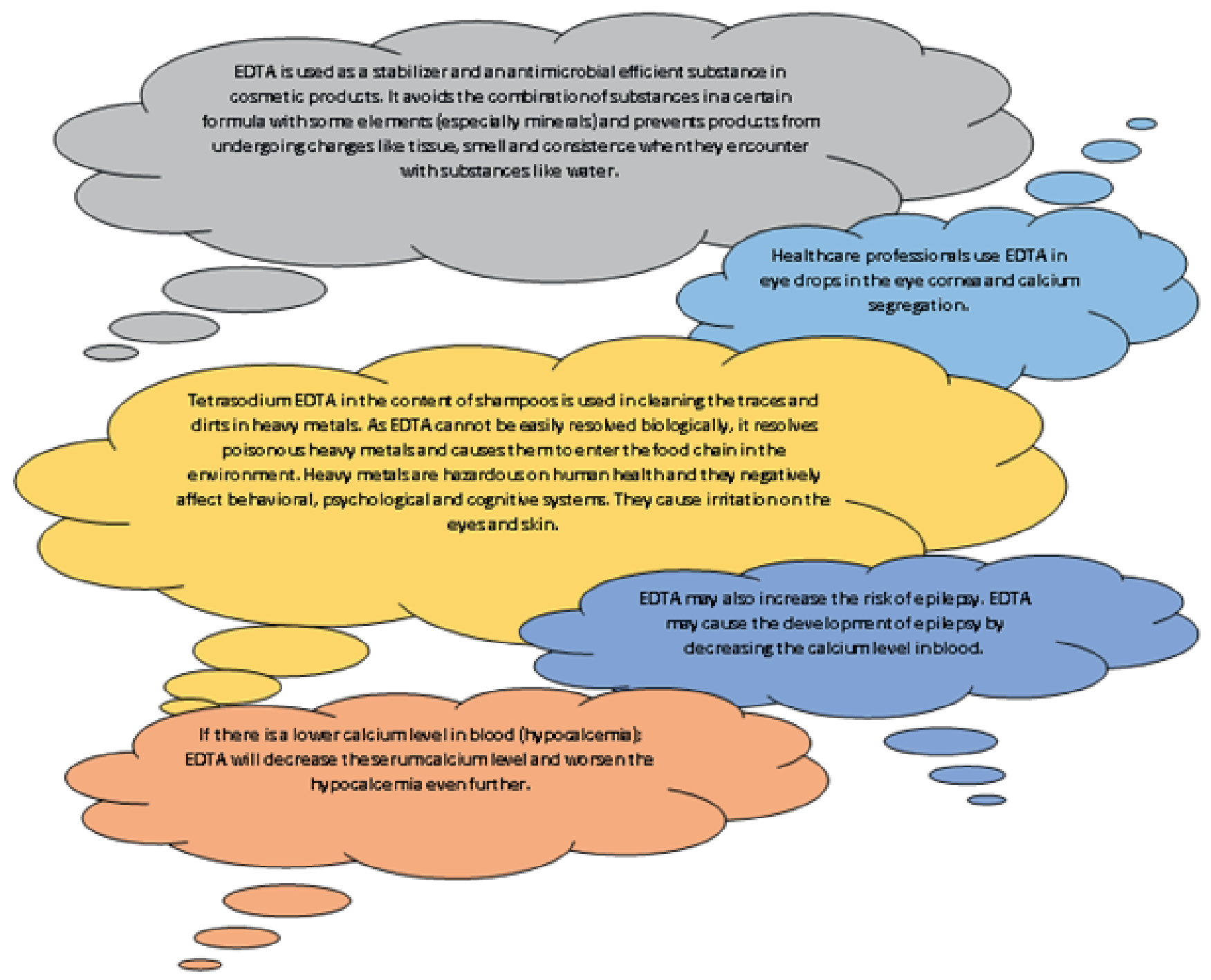

